NEW FROM MACMILLAN

REVIEWS ON IMMUNOASSAY TECHNOLOGY VOLUME 3

Edited by S. B. Pal

Contents

Strategies for the Isolation of Antigen-Specific B Lymphocytes - R. P. Phipps (Rochester, USA)

Clq, A Subcomponent of the First Complement Component: Methods for the Isolation from Various Animals - K. Yonemasu \& T. Sasaki (Nara, Japan)

Recent Developments in the Use of Liposomes in the vitro Diagnostic Assays - V. T. Kung (Palo Alto, USA) \& E. Canova-Davis (San Francisco, USA)

Immunoenzymatic Stainings in Diagnostic Virology - M. Musiani \& M. Zerbini (Bologna, Italy)

A Novel Homogeneous B-Galactosidase Immunoassay System

- D. Monroe (Memphis, USA)

Enzyme Channelling Immunoassay (ECIA): A Unique \& Rapid Quantitative Technique - D.

Monroe (Memphis, USA)

Determination of Antibody to

Respiratory Pathogens - Ya S.

Schwartzman \& L. E. Kamforin

(Leningrad, USSR)

Double Immunocytochemical Staining Method - H. Sako, Y. Nakane, K. Okino, K. Nishihara, M. Kodama, H. Yamada \& M. Kawata (Seta, Japan)

Interpolation in Assay Systems with a Sigmoid Response Curve - K. R. S. Osterloh (New York), G. D. Smith (Harrow) \& T. J. Peters (Harrow) Immunocytochemical Localization of Peroxisomal Enzymes in Rat Liver \& Kidney Revealed by Immunoenzyme and Immunogold Techniques - S. Yokota (Yamanishi, Japan)

Index

November 1989 0-333-49795-3 $£ 40.00 \quad 208 \mathrm{pp} \quad 234 \times 156 \mathrm{~mm}$ Volumes 1, 2, 3 \& 4 are available from your local bookseller or from:

Dionne Stocking, Macmillan Press Ltd, Houndmills, Basingstoke, RG21 2XS, UK.

\section{The northern light}

\author{
David W. Hughes
}

James Joule: A Biography. By Donald S.L. Cardwell. Manchester University Press: 1989. Pp.333. £35, \$59.95.

James Prescott Joule, the Prescott being his mother's family name and the Joule, rhyming with cool, originating from the Derbyshire village of Youlgreave, was a Manchester/Salford man through and through. He was born on Christmas Eve 1818 into a famous brewing family and spent some of his early years working for the firm. Eventually his scientific interests predominated and it is said that the requirements of brewing technology and the accountancy needed to run a business helped to mould his scientific attitudes. A spinal weakness at birth turned him into a hunchback, and this shy and unassertive man was always sensitive about his public appearances.

Science in the time of Joule was changing from being the affair of the gentleman devotee to being the occupation of the full-time professional, ensconced in the university laboratory. Joule was in the first category. Almost all of his research was carried out in his laboratory at home and at his own expense.

According to my old science master, Joule's maxim was that "when you work you get hot". Reading Cardwell's biography one quickly realizes just why Joule is so often treated with such flippancy. His reticence often meant that his discoveries were attributed to more verbose and flamboyant researchers. Joule was a scientist's scientist. His main interest lay in exact measurement and his special genius showed itself at its best in the invention of methods for obtaining greater accuracy in quantitative experiments. $\mathrm{He}$ was systematic and hard-working discreet about the origin of his ideas and cautious about his speculation.

Joule found that the heat generated by the flow of electricity was proportional to the electrical resistance multiplied by the square of the current. His experimental skills firmly established the law of conservation of energy. We take this law for granted now, but in Joule's time the complete conversion of heat into work or work into heat was no more conceivable than the conversion of gravity into hydrogen or hydrogen into gravity.

There was, too, his paddle-wheel experiment, which showed that any fluid could be heated merely by agitating it. One never forgets that because of this simple fact the water that has dropped the $49 \mathrm{~m}$ over Niagara Falls is $0.11^{\circ} \mathrm{C}$ higher in

\section{IMAGE UNAVAILABLE FOR COPYRIGHT REASONS}

James Prescott Joule - a scientist's scientist. (Mary Evans Picture Library.)

temperature than at the top. More prosaically, one can state (in old units surely) that the work done in raising a weight of $1 \mathrm{lb}$ through $772 \mathrm{ft}$ will, if converted into heat, raise the temperature of $1 \mathrm{lb}$ of water by one degree Fahrenheit. The ratio between the heat and the work was termed $J$, this symbol being introduced by Lord Kelvin (William Thomson) in honour of Joule, his friend.

Joule also noted that the adiabatic expansion of gases leads to cooling, on account of work being done against the intermolecular forces. Experimental investigation into this process, in conjunction with Lord Kelvin, then professor of natural philosophy at the University of Glasgow, led to the gradient of an isenthalpic curve being known as the Joule-Kelvin coefficient.

Joule died 100 years ago, and in this timely biography Cardwell has done full justice to his subject. Not only has he carefully placed Joule's work in the context of the scientific aspirations of his contemporaries, he has also delved deeply into a huge collection of primary material and thus produced a definitive picture of the man and his work. The end result is a book that is not only eminently readable but is also an excellent work of reference and a fascinating introduction to James Joule and to the state of British science in the mid 1800 s.

David W. Hughes is in the Department of Physics, University of Sheffield, Sheffield S3 $7 R H$, UK. 